KULTURA

i

\title{
KULTURA I EKONOMIA W PROCESIE INTEGRACJI MUZUŁMANÓW EUROPEJSKICH
}

\section{„KULTURA MA ZNACZENIE”}

Rodzima kultura ma duże, ale różne znaczenie dla kolejnych pokoleń imigrantów osiadłych w krajach Europy Zachodniej ${ }^{1}$. Co więcej, każde pokolenie imigrantów żyje w „trochę innej” kulturze zachodniej, która ewoluuje dziś tak szybko jak nigdy dotychczas. Dla muzułmanów z Afryki Północnej, Bliskiego Wschodu lub Azji Południowej przybyłych i przybywających do Europy Zachodniej rozdarcie między tradycyjną, wiejską kulturą rodzimą a nowoczesną, miejską kulturą Zachodu może przyjmować dramatyczne formy. Ujawniające się różnice kulturowe domagają się trudnych wyborów lub kompromisów. Adaptacja do kultur europejskich jest tym trudniejsza, że sami Europejczycy się zmieniają. Spójność i tożsamość starych kultur europejskich rozmywa się w wyniku oddziaływania postępu technicznego, globalnej popkultury i interakcji międzykulturowych. Kultura zastana przez pierwszych powojennych imigrantów europejskich była odmienna, mniej liberalna od tej, w której przyszło dorastać drugiemu i trzeciemu pokoleniu. Kolejne pokolenia imigrantów asymilują się, przeżywają wewnętrzny konflikt wartości albo okopują się w fundamentalizmie kulturowym. W takiej sytuacji trudno przewidzieć losy kulturowej integracji europejskich imigrantów.

Jeśli patrzymy na problem $z$ drugiej strony, to największym wyzwaniem dla procesu kulturowej integracji Europy jest dziś odmienność jej nowych obywateli - muzułmańskich imigrantów i ich dzieci, często obywateli już nowych

\section{Adres do korespondencji: pasamon@aps.edu.pl}

${ }^{1}$ Śródtytuł nawiązuje do tytułu książki pod redakcją Lawrence’a E. Harrisona i Samuela P. Huntingtona Kultura ma znaczenie. Jak wartości wptywaja na rozwój społeczeństw, której polski przekład ukazał się w $2003 \mathrm{r}$. 
ojczyzn. Jest to dziś najliczniejsza mniejszość kulturowa na naszym kontynencie - szacuje się, że w Europie Zachodniej żyje około 20 mln muzułmanów (Pryce-Jones 2004).

Przypomnijmy, że muzułmańscy imigranci pojawili się w Europie, po drugiej wojnie światowej, w latach pięćdziesiątych XX wieku, w okresie gwałtownego rozwoju gospodarczego, który spowodował otwarcie się rynku francuskiego na siłę roboczą z krajów Maghrebu. Aż do lat siedemdziesiątych migrowali samotni mężczyźni. Był to okres „ukrytej obecności islamu” (Bujis, Rath 2002, s. 23). Praktyki religijne ograniczano do codziennych modlitw indywidualnych i celebrowania największych świąt. Wielu imigrantów nie stroniło od spożywania alkoholu i nie dbało o koszerność spożywanej żywności (halal). Imigracja zarobkowa nie myślała o budowaniu meczetów ani o lekcjach religii dla swoich dzieci. Jak trafnie zauważył Trevor Jones (1993, s. 24): „imigranci mieszkali i pracowali w Wielkiej Brytanii w imieniu swoich rodzin, które z kolei modliły się w ich imieniu".

$\mathrm{W}$ połowie lat siedemdziesiątych w ślad za pierwszą falą migracji masowo podążyły rodziny. Przybycie do Europy żon i dzieci imigrantów stanowi punkt zwrotny w rozwoju islamu europejskiego - tradycyjne normy i wartości islamu zostają odnowione. Islam staje się dla imigrantów na powrót systemem wartości regulującym wszystkie sfery życia. „Połączenie rodzin oznaczało silniejszą kontrolę społeczną w obrębie społeczności muzułmańskich. Przejście od statusu pracownika czasowego, podtrzymywanego przez «mit powrotu», do decyzji o osiedleniu się na stałe oznaczało m.in. koniec kawalerskiego trybu życia niektórych imigrantów" (Pędziwiatr, 2005, s. 29). Pojawiają się muzułmańskie sklepy $z$ dewocjonaliami, masarnie $z$ mięsem halal, szkoły koraniczne i, rzecz jasna, meczety. Jednocześnie połączenie się członków rodzin wpływa na poszerzenie zakresu interakcji imigrantów ze społeczeństwami przyjmującymi (placówki służby zdrowia, szkoły).

Pierwsze pokolenie, które osiedliło się w nowym świecie, żyło w rozdarciu, łącząc cechy starego i nowego porządku. Brak kompetencji kulturowych uniemożliwiał pełne włączenie się $\mathrm{W}$ sferę publiczną nowego społeczeństwa. Jak zauważył Pierre Bourdieu (1991), osoby takie funkcjonują na granicy społecznego bytu i niebytu, nie przynależą w pełni do społeczeństwa przyjmującego, ani do oddalonego nierzadko o setki kilometrów społeczeństwa wysyłającego. Pierwsze pokolenie imigrantów myślało o sobie nie tylko jako o muzułmanach, ale także jako o Marokańczykach, Algierczykach, Turkach czy Pakistańczykach. Dlatego europejski islam jest dziś zabarwiony etnicznie: francuski nosi charakter północnoafrykański, o silnym rysie walki antykolonialnej, niemiecki jest bliskowschodni, naznaczony polityką sekularyzacyjną Kemala Ataturka, a brytyjski ma charakter południowoazjatycki z cechami sufizmu.

Drugie pokolenie imigrantów nie wyrzeka się religii i kultury swoich rodziców, ale praktykuje ją w odmienny sposób. Po pierwsze, odróżnia islam 
jako religię od islamu jako kultury. Samoidentyfikacja religijna wśród drugiego pokolenia muzułmanów bierze górę nad tożsamością etniczną. Nowa tożsamość muzułmańska jest ponadnarodowa i pozwala na aktywniejszy udział w życiu społecznym (Cesari 1994; Modood, Berthoud 1997; Peach, Vertovec 1997).

Część młodych muzułmanów zachowuje dystans wobec instytucji religijnych, wyznając islam $w$ sposób zindywidualizowany i ograniczony do sfery prywatnej. Inni nie godzą się na to, by wpływy ich religii były ograniczone do sfery prywatnej i domagają się uznania swojej tożsamości na forum publicznym. Posiadając prawa obywatelskie i kompetencje kulturowe, przejmują kontrolę nad organizacjami muzułmańskimi i walczą o większe prawa lub przywileje dla swoich współwyznawców.

Jeszcze inna część europejskich muzułmanów uległa laicyzacji, ale pozostała w obrębie kultury muzułmańskiej. Nie stosuje się do nakazów religijnych islamu, ale funkcjonuje $\mathrm{w}$ obrębie muzułmańskiego uniwersum symbolicznego. „Uniwersum symboliczne jest rodzajem filtru, przez który patrzą na świat, i płaszczyzną porozumienia - choć różnią ich poglądy polityczne, normy i wartości, potrafią się ze sobą porozumieć, gdyż podzielają podstawowe symbole, obrazy, znaczenia mające swe źródło w islamie (Pędziwiatr 2005, s. 43-44).

Do lat siedemdziesiątych kraje europejskie były nastawione dosyć przychylnie do nowych sąsiadów. Jednak z końcem lat osiemdziesiątych recesja w gospodarce, wysokie wskaźniki bezrobocia, wzrastająca liczba imigrantów i ich „nieeuropejski” charakter doprowadziły do radykalnych zmian w nastawieniu i polityce Europejczyków. Fala zamachów terrorystycznych z początku naszego wieku rozbudziła w Europejczykach islamofobię, rasizm i nietolerancję. Dziś europejskie gazety rozpisują się o „muzułmańskim problemie Europy”.

Czy mamy dziś do czynienia z prognozowanym przez Samuela Huntingtona zderzeniem kultur? I tak, i nie. Odpowiedź na to pytanie nie jest prosta ani jednoznaczna. Będę jej poszukiwała w wynikach badań Instytutu Gallupa i Światowego Sondażu Wartości. Pokażę jednocześnie ograniczoną miarodajność tych badań dla analizy procesu integracji kulturowej europejskich muzułmanów.

Sięgając do sondaży Instytutu Gallupa spróbuję sprawdzić, w jakim stopniu europejscy muzułmanie i rdzenni Europejczycy stanowią dwa monolityczne fronty ewentualnego zderzenia cywilizacji - pokażę wewnętrzne zróżnicowanie społeczności muzułmańskich i zachodnich. Na podstawie danych z Światowego Sondażu Wartości przyjrzę się generacyjnej ewolucji poglądów i zachowań trzech pokoleń europejskich muzułmanów oraz aktualnym liniom podziałów kulturowych. Na koniec, przeanalizuję pozakulturowe czynniki wpływające na społeczno-kulturowy proces integracji (bezrobocie) i zastanowię się, czy różnice kulturowe (lub które różnice kulturowe) mają dziś decydujący wpływ na przebieg procesu integracji społeczno-kulturowej. 


\section{EUROPEJSKIE ZDERZENIE CYWILIZACJI: INGLEHART TESTUJE HUNTINGTONA}

W 1993 r. Samuel Huntington, amerykański politolog z Uniwersytetu Harwardzkiego, poruszył opinię publiczną śmiałą tezą, jakoby przyszłą politykę światową miały zdominować zderzenia między cywilizacjami. Artykuł pt. The Clash of Civilizations ukazał się w „Foreign Affairs” latem 1993 r., a rozwinięcie hipotezy w książce Zderzenie cywilizacji i nowy ksztatt ładu światowego w $1996 \mathrm{r}$. (wyd. pol. 2001) Huntington był przekonany, że po epoce zimnej wojny paradygmat „zderzenia cywilizacji” najlepiej tłumaczy procesy zachodzące na świecie. Według amerykańskiego politologa, ani ideologie, ani gospodarka nie są już wystarczającymi źródłami konfliktów międzynarodowych. Stają się nimi różnice kulturowe, wywodzące się w znacznej mierze $z$ podziałów religijnych. To kultura i tożsamość kulturowa, będąca w szerokim pojęciu tożsamością cywilizacji, mają kształtować wzorce spójności, dezintegracji i konfliktu w świecie po 1991 r. (zob. Huntington 2001).

Huntington przekonywał, że demokracja „liberalna” jest możliwa obecnie tylko i wyłącznie w państwach kultury zachodniej. Reszta świata - choć eksperymentująca $z$ demokratyzacją - na dzisiejszym etapie rozwoju musi zadowolić się „demokracją wyborczą” (inaczej: sterowaną, kontrolowaną). Huntington przestrzegał przed iluzją utożsamiania modernizacji, jaka dokonuje się w krajach „niezachodnich”, z procesem ich westernizacji. Pokazywał, że ruchy odrodzenia religijnego są antylaickie, antyuniwersalistyczne, a także ( $z$ wyjątkiem chrześcijaństwa) antyzachodnie. Najbardziej dramatyczne konflikty miałyby wynikać $z$,arogancji Zachodu, nietolerancji islamu i chińskiej pewności siebie". Huntington wskazywał na zderzenie religijnego islamu z coraz bardziej świeckim chrześcijaństwem, totalitaryzmu z demokracją, kolektywizmu $z$ indywidualizmem.

Długofalowe badania Światowego Sondażu Wartości (World Values Survey - WVS) częściowo potwierdzają, jak się wydaje, tezę Huntingtona, że obie cywilizacje oddalają się od siebie kulturowo. Społeczności Europy Zachodniej mimo oczywistych różnic językowych i kulturowych rozwijają się dziś w zbliżony sposób. Najważniejsze wartości, takie jak prawa człowieka lub ochrona środowiska, stają się w coraz większym stopniu wspólne dla wszystkich narodów europejskich. Kierujący sondażem od 1988 r. Ronald Inglehart odnotował długookresową zmianę w wyznawanych wartościach, polegającą na ewolucji ku tzw. wartościom postnowoczesnym (Inglehart, Norris 2003a). Oznacza to, że współcześni ludzie są bardziej tolerancyjni, otwarci, przychylni zmianom niż ludzie należący do świata wartości nowoczesnych. Jednak ta głęboka i trwała zmiana w kierunku tolerancji zachodzi tylko w krajach wysoce rozwiniętych tylko tam rośnie uznanie i sympatia dla różnorodności, ochrony środowiska, równości kultur, religii, płci, orientacji seksualnych. W ciągu ostatnich trzech dekad podstawowe wartości Zachodu (Europy Zachodniej, Stanów Zjednoczo- 
nych, Kanady, Australii) zmieniły się zasadniczo, podczas kiedy reszta świata albo pozostaje niezmienna, albo się zmienia w przeciwnym kierunku. W wielu biednych krajach społeczeństwa stają się coraz bardziej konserwatywne i mniej tolerancyjne. Dobrą ilustracją tych rozbieżności jest stosunek do problemów społecznych związanych z płcią.

Analiza badań WVS, opublikowana w „Foreign Policy” w 2003 r. (dziesięć lat po artykule Huntingtona), pokazała, że kultury muzułmańską i zachodnią bardziej różni dziś eros niż demos - bardziej różnią nas kwestie obyczajowe, wartości moralne aniżeli poparcie dla demokracji (Inglehart, Norris 2003b). Prowadzący badania stwierdzili, że w kwestii równości płci i seksualnej liberalizacji różnica między islamem a Zachodem niebezpiecznie się pogłębia.

Tablica 1

Wartości polityczne i społeczne w społeczeństwach zachodnich i muzułmańskich

\begin{tabular}{|l|c|c|}
\hline $\begin{array}{c}\text { Badany obszar: wartości } \\
\text { polityczne i społeczne }\end{array}$ & $\begin{array}{c}\text { Respondenci zachodni: procent } \\
\text { popierających / akceptujących }\end{array}$ & $\begin{array}{c}\text { Respondenci muzułmańscy: } \\
\text { procent popierających / } \\
\text { akceptujących }\end{array}$ \\
\hline Demokratyczna praktyka & 68 & 68 \\
Demokratyczne idee & 86 & 87 \\
Równość płci & 82 & 55 \\
Rozwody & 60 & 35 \\
Aborcja & 48 & 25 \\
Homoseksualizm & 53 & 12 \\
\hline
\end{tabular}

Źródło: Światowy Sondaż Wartości, próba z lat 1995-2001, obejmująca ponad siedemdziesiąt krajów (Inglehart, Norris 2003b).

Różnimy się więc odpowiedziami na pytania: czy mężczyźni są lepszymi przywódcami politycznymi niż kobiety, czy mężczyźni mają większe prawo do pracy niż kobiety, czy edukacja uniwersytecka jest ważniejsza dla chłopców niż dla dziewcząt, czy kobieta musi mieć dzieci, żeby się spełnić, czy kobiety powinny mieć prawo do samotnego rodzicielstwa (Inglehart, Norris 2003b, s. 175). Dla ludzi w biednych krajach pozycja kobiet w społeczeństwach zachodnich — niezależność ekonomiczna, swoboda seksualna, role, które pełnią — jest już szokująca. Drugorzędne różnice sprzed pięćdziesięciu lat przerodziły się w przepaść, która wciąż się pogłębia.

Niebagatelną rolę $\mathrm{w}$ tym procesie odegrała rewolucja seksualna lat sześćdziesiątych. Wyzwoliła jednostkę od kulturowych ograniczeń i opresji seksualnych, a zarazem przyczyniła się do komercjalizacji seksu (rozwoju coraz bardziej wyrafinowanych potrzeb seksualnych i rynku je zaspokajającego). Tradycyjni muzułmanie podzielają głosy współczesnych neokonserwatystów, którzy tę „z piekła rodem rewolucję” obarczają winą za obyczajową deprawację zachodnich społeczeństw (zalew pornografii, rozpasanie seksualne, gwałt w rodzinie i zalegalizowanie związków homoseksualnych). Dla kobiet rewolucja 
seksualna oznaczała jednak ich kulturową emancypację: polityczne i społeczne uznanie równości płci oraz swobodę seksualną i prokreacyjną — obszary ściśle regulowane do tej pory przez religię i kulturę.

Dzisiejsza polaryzacja postaw wobec kobiet dokonuje się w kontekście coraz liczniejszych interakcji Zachodu $z$ islamem. Polem dla tych interakcji są wielokulturowe społeczeństwa europejskie. Im bardziej Zachód się liberalizuje, tym bardziej świat muzułmański się polaryzuje. W miarę postępującej liberalizacji obyczajowej rośnie podział wewnętrzny społeczności muzułmańskich: kiedy część podąża za zachodnimi wzorami, inna część stawia opór asymilacyjny i kurczowo trzyma się starych tożsamości religino-kulturowych. Można zaryzykować twierdzenie, że to Zachód sprowokował współczesne zderzenie wartości w łonie islamu. Według Ingleharta i Norris (2003b), mamy dziś do czynienia przede wszystkim z „seksualnym zderzeniem cywilizacji”. Przy czym ani Huntington, ani Inglehart nie doceniają wewnętrznego zderzenia systemów wartości. A przekonująca teza Ingleharta o seksualnym zderzeniu wartości oparta jest na fałszywych przesłankach, co będę starała się wykazać po przedstawieniu dalszej części badań Światowego Sondażu Wartości.

\section{INTEGRACJA MUZUŁMANÓW POSTĘPUJE}

W pierwszej dekadzie XXI wieku doszło do kilku spektakularnych zamachów terrorystycznych i wydarzeń, które podały w wątpliwość integrację europejskich muzułmanów:

— zamachy terrorystyczne: 11 września w Stanach Zjednoczonych (2001), Madryt (2004), Londyn (2005);

- zamieszki etniczne wywołane zabójstwem holenderskiego reżysera Theo van Gogha przez islamskiego ekstremistę (listopad 2004);

- gwałtowne protesty wywołane publikacją karykatur Mahometa w duńskim piśmie (wrzesień 2005-marzec 2006);

— zamieszki na imigranckich przedmieściach Paryża $(2005,2006)$.

Po tragicznym zamachu na World Trade Center politycy, media, a także politolodzy i socjolodzy, obwieścili światu, że Zachód (w tym Europa) ma problem z muzułmanami, którzy nie potrafią lub nie chcą się zintegrować. Słynna teza Huntingtona powróciła i awansowała do rangi głównego paradygmatu myślenia o relacjach między Zachodem i islamem. Polityczna poprawność zaczęła ustępować krytyce, coraz jawniejszej niechęci czy wręcz islamofobii.

Zupełnie nowe światło na proces integracji europejskich muzułmanów rzucają znowu długofalowe badania Światowego Sondażu Wartości. Kierujący badaniami Ronald Inglehart postanowił sprawdzić, jak dalece imigranci trwają przy swojej kulturze na obczyźnie, a do jakiego stopnia przyjmują kulturę kraju osiedlenia (Inglehart, Norris 2009). Testowano dwie konkurencyjne teorie dotyczące współczesnej imigracji: teorię integracji kulturowej i dywergencji kulturowej. 
Teoria integracji kulturowej przewiduje, że jeśli istnieje duża rozpiętość pomiędzy kulturami zachodnią i islamską (postawa wobec rodziny, małżeństwa, ról kobiecych), to imigranci będą stopniowo podzielać dominujące wartości kraju przeznaczenia. Według alternatywnej teorii dywergencji kulturowej w takiej sytuacji różnice między kulturami będą się nie tylko utrzymywać, ale wręcz pogłębiać.

W ramach WVS badano, czy podstawowe wartości muzułmańskich imigrantów są bliższe tym wyznawanym w społecznościach pochodzenia, czy też tym obowiązującym $\mathrm{w}$ społeczeństwach docelowych, przyjmujących. $\mathrm{W}$ analizach zastosowano cztery wskaźniki:

- równości płci²,

— liberalizacji seksualnej ${ }^{3}$,

- religijności ${ }^{4}$,

- demokratycznych wartości ${ }^{5}$.

Badania WVS objęły lata 1981-2007, sondaż powtórzono pięć razy, porównywano dwa rodzaje społeczeństw: origins (islamskie państwa, z których pochodzą muzułmańscy emigranci) i destination (zachodnie kraje, do których imigrują muzułmanie). Sondaż objął kraje arabskie zarówno z przewagą sunnitów (Jordan, Algieria, Maroko, Egipt), jak i szyitów (Irak), kraje azjatyckie (Azerbejdżan, Kirgistan, Pakistan, Bangladesz, Malezja), Europę Środkową (Bośnia, Hercegowina, Albania) i subsaharyjską Afrykę (Mali, Burkina Faso); zarówno kraje, których islam jest fundamentem instytucji politycznych (Arabia Saudyjska, Pakistan), kraje, w których islam jest oficjalną religią państwową (Egipt, Bangladesz, Malezja), jak i kraje świeckie (jak Turcja, Azerbejdżan, Indonezja).

Inglehart i Norris przyjęli hipotezę - za Bergerem i Luckmanem —że orientacja wykształcona w czasie socjalizacji pierwotnej obejmująca role płciowe, tożsamość etniczną i wartości religijne stanowi rdzeń tożsamości osobowej i $z$ tego powodu jest względnie odporna na zmiany. $Z$ kolei wartości polityczne i ekonomiczne są kształtowane $\mathrm{w}$ procesie socjalizacji wtórnej i dlatego są bardziej podatne na zmiany. Badacze zatem spodziewali się, że imigranci łatwiej zmieniają poglądy polityczne aniżeli dotyczące religii i ról płciowych.

${ }^{2}$ Wskaźnik równości płci obejmował pytania: czy mężczyźni są lepszymi liderami politycznymi niż kobiety, czy edukacja uniwersytecka jest ważniejsza dla mężczyzn, czy mężczyźni mają większe prawo do pracy niż kobiety.

3 Wskaźnik liberalizacji seksualnej obejmował pytania o dopuszczalność aborcji, rozwodów i homoseksualizmu.

4 Wskaźnik religijności obejmował pytania o: znaczenie wiary w Boga i religii, tożsamość religijną, uczęszczanie do miejsc kultu, praktykowanie modlitwy lub medytacji, rozmyślanie o sensie życia.

${ }^{5}$ Wskaźnikiem poparcia dla demokracji był wybór jednej spośród następujących opcji: rządy silnego lidera bez wyborów, decyzje podejmują eksperci, a nie rząd, rządy armii, aprobata dla systemu demokratycznego. 
Wykres 1

Wartości imigrantów muzułmańskich a wartości społeczeństw pochodzenia i osiedlenia (stopień poparcia, $\mathrm{w} \%$ )

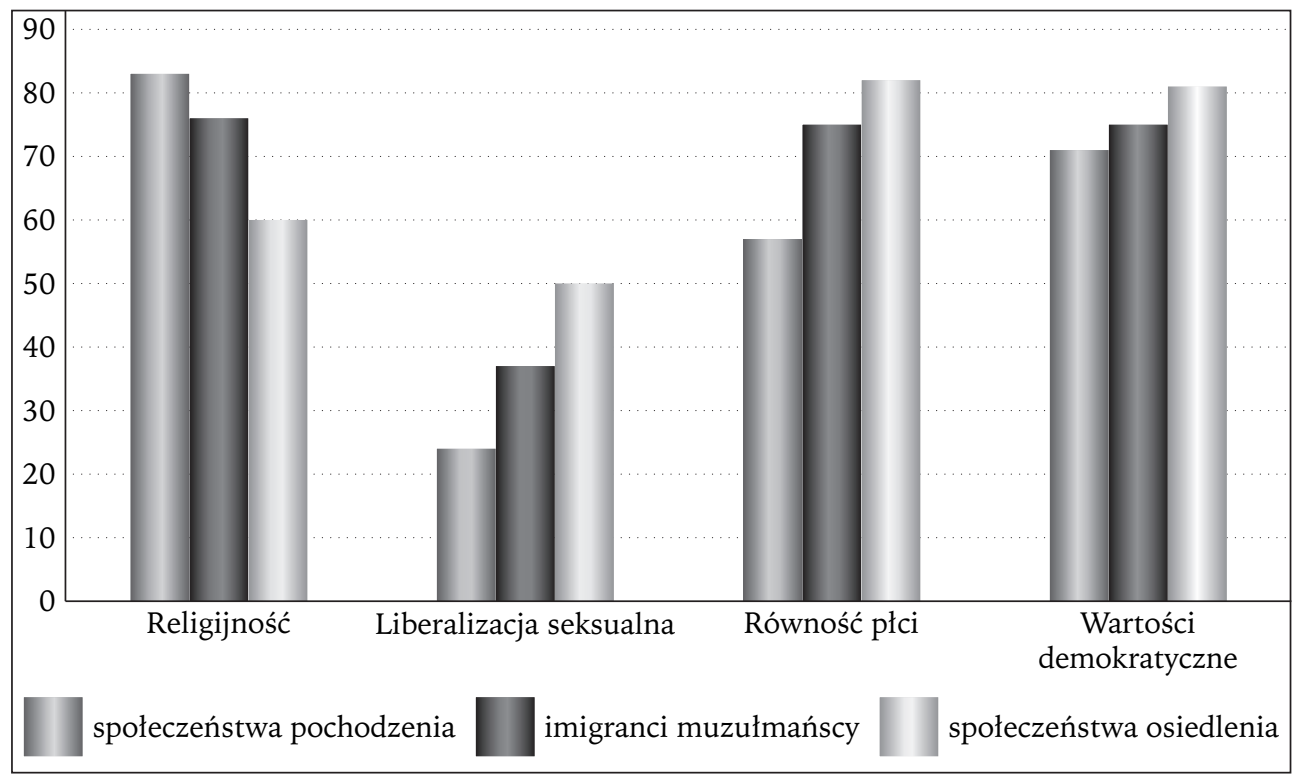

Źródło: Światowy Sondaż Wartości 1981-2007 (Inglehart, Norris 2009).

Analiza wyników przeprowadzonych badań pozwala stwierdzić, że podstawowe wartości muzułmanów żyjących w społeczeństwach zachodnich są $\mathrm{w}$ połowie drogi pomiędzy wartościami dominującymi w kraju pochodzenia i w kraju osiedlenia. Innymi słowy, społeczności muzułmańskie żyjące w zachodnich miastach znajdują się w toku adaptacji do kultury zachodniej, choć w tym samym czasie kultywują wartości nabyte podczas socjalizacji pierwotnej w krajach pochodzenia.

Najbardziej upodabnia poparcie dla demokracji (muzułmanie-imigranci $71 \%$, społeczeństwa zachodnie $81 \%$ ), największy dystans kulturowy przejawia się w obszarze liberalizacji seksualnej (muzułmanie-imigranci 37\%, społeczeństwa zachodnie 50\%). Jak można się spodziewać, największe poparcie dla swobody obyczajowej wykazują osoby wykształcone, mające pracę i lepiej zarabiające, a najsłabszego poparcia udzielają imigranci najstarsi, pozostający w związku małżeńskim, mężczyźni i jednostki najbardziej religijne.

Z sondażu wynika, że poparcie dla równości płci wśród zachodnich muzułmanów (75\%) jest istotnie wyższe (o 38 punktów) od zgody na liberalizację seksualną (37\%). Zauważmy jednak, że w społeczeństwach zachodnich akceptacja dla równouprawnienia (82\%) jest większa o 32 punkty od akceptacji dla liberalizacji seksualnej (50\%). Poparcie dla równouprawnienia plasuje się 
między poparciem dla demokracji a niezgodą na liberalizację seksualną. Teza Ingleharta z roku 2003 domaga się więc uściślenia: różni nas nie tyle poparcie dla równych praw kobiet i mężczyzn, ile liberalizacja obyczajowa.

Inglehart i Norris dowodzą, że życie w kraju islamskim lub zachodnim odciska o wiele większe piętno na praktykowaniu wartości niż indywidualna tożsamość religijna lub indywidualna edukacja, wiek, płeć czy dochody. Te zaskakujące konkluzje znajdują oparcie w innych badaniach, w których Ronald Inglehart i Christian Welzel (2005) porównywali pluralistyczne społeczeństwa z dwiema osiadłymi społecznościami religijnymi — byli to katolicy i protestanci w Niemczech, hinduiści i muzułmanie w Indiach, chrześcijanie i muzułmanie w Nigerii. Wyniki tych badań również okazały się zaskakujące: podstawowe wartości muzułmanów z Nigerii były bliższe wartościom ich katolickich współrodaków niż muzułmanów indyjskich.

Inglehart jest optymistą — według niego życie w jednym kraju ma większy wpływ na system wartości aniżeli wyniesiona $z$ domu wiara i chociaż tolerancja dla liberalizacji seksualnej oraz poparcie dla równości płci stanowią kluczowy aspekt demokratycznej polityki kulturalnej, nie jesteśmy skazani na zderzenie cywilizacji. Wprawdzie wysoki poziom niepewności egzystencji generuje ksenofobię i nietolerancję, które prowadzą do przemocy, lecz wraz ze wzrostem poczucia bezpieczeństwa rośnie tolerancja dla różnorodności, a kulturowy pluralizm jest postrzegany jako wzbogacający różnorodność stylów życia. Konflikt kulturowy nie jest więc nieuchronny. To warunki życia determinują ostatecznie sposób postrzegania różnorodności: jako zagrażającej lub pozytywnej.

Obecny kryzys gospodarczy rzuca cień na optymizm Ingleharta - destabilizacja rynków światowych wpływa na niepewność lub niemożność zatrudnienia. Brak stabilizacji ekonomicznej bezpośrednio generuje brak poczucia bezpieczeństwa, a więc rośnie zagrożenie konfliktem kulturowym na tle rywalizacji o pracę. Poza tym dane Światowego Sondażu Wartości wydają się dyskusyjne z kilku powodów:

— Inglehart konfrontuje „cały świat Zachodu” z „całym światem islamu”, łącząc w jedną grupę zlaicyzowane kraje Europy Zachodniej i religijne Stany Zjednoczone. Tak duże uogólnienie stawia pod znakiem zapytania wnioski dotyczące różnicy religijności napływowych muzułmanów i zachodnich społeczeństw rodzimych. Można się spodziewać, że jest ona dużo większa w Europie Zachodniej niż w Stanach Zjednoczonych.

- Kontrowersyjna wydaje się konstrukcja wskaźników liberalizacji seksualnej i równości płciowej. Wskaźnik równości płci obejmuje tylko trzy pytania: czy mężczyźni są lepszymi liderami politycznymi niż kobiety, czy edukacja uniwersytecka jest ważniejsza dla mężczyzn, czy mężczyźni mają większe prawo do pracy niż kobiety. Są to pytania o równouprawnienie w polityce, edukacji i na rynku pracy - brakuje zaś pytań o równouprawnienie $\mathrm{w}$ zakresie wolności osobistej: wyrażania swoich poglądów, wyboru szkoły, zawodu, męża, możliwości wychodzenia $z$ domu, podziału domowych obowiązków. Wskaź- 
nik liberalizacji seksualnej też obejmuje tylko trzy pytania: o akceptację dla aborcji, rozwodów i homoseksualizmu. Jak pokazuje cytowany dalej sondaż Gallupa, w sprawie aborcji i homoseksualizmu mieszkańcy Zachodu również mają bardzo zróżnicowane poglądy i nikogo to nie martwi, gdyż żyjemy w społeczeństwach pluralistycznych. Nie przekonuje więc diagnozowanie procesu integracji muzułmanów na podstawie zgodności poglądów w tak kontrowersyjnych kwestiach. Jest przy tym prawdopodobne, że różny stosunek do liberalizacji seksualnej faktycznie powoduje konflikty międzykulturowe i wewnątrzkulturowe. W WVS brakuje jednak pytań o codzienne przejawy liberalizacji seksualnej, takie jak akceptacja dla przedmałżeńskiego seksu czy tolerancja dla liberalnej mody i stylu życia.

- W końcu zastrzeżenie może budzić diagnoza dotycząca procesu integracji zachodnich muzułmanów sformułowana na podstawie badania ich poglądów, bez weryfikacji, jakie są faktyczne zachowania jednostkowe i społeczne (zwłaszcza w przypadku liberalizacji seksualnej). WVS powinien być uzupełniony o pogłębione wywiady lub studia przypadków.

\section{LIBERALIZM OBYCZAJOWY DZIELI WSZYSTKICH}

Hipoteza Samuela Huntingtona, podtrzymana częściowo, w zmodyfikowanej wersji przez Ronalda Ingleharta, opiera się na bilateralnym przeciwstawieniu kultur islamu i Zachodu. Taka interpretacja sugeruje, że każda ze stron przemawia jednym głosem w kwestiach moralności, tolerancji i wolności seksualnej. Zachód jawi się jako monolitycznie liberalny, a islam jako monolitycznie konserwatywny. Kilka nowych sondaży badawczych przeprowadzonych przez Gallup Poll podważa takie monolityczne spojrzenie na „strony konfliktu kulturowego" i ukazuje wewnętrzne zróżnicowanie Zachodu co do podzielanych wartości.

Magali Rheault i Dalia Mogahed (2008c) przedstawili wyniki sondażu przeprowadzonego w latach 2006-2008 w trzech stolicach europejskich: Paryżu, Londynie i Berlinie. Porównywano poglądy moralne rdzennych mieszkańców trzech stolic i zamieszkałych $\mathrm{w}$ nich społeczności muzułmańskich. Zestawiono je $z$ poglądami przeciętnych i religijnych Amerykanów. Przedmiotem badań była akceptacja moralna dla czterech kontrowersyjnych moralnie zachowań: aktów homoseksualnych, aborcji, oglądania pornografii i seksu przed/pozamałżeńskiego.

Znaczącej akceptacji dla homoseksualizmu udzielili: Francuzi (81\%), Niemcy (68\%) i Brytyjczycy (66\%). Amerykanie z akceptacją $48 \%$ uplasowali się między Europejczykami a europejskimi muzułmanami. Wyraźnie rzadziej akceptację dla homoseksualizmu wykazywali muzułmanie: w Berlinie (26\%), Paryżu (18\%), Londynie (4\%) i religijni Amerykanie (28\%). Średnio Francuzi, Niemcy i Brytyjczycy tolerują homoseksualizm w 71\%, a muzułmanie w Londynie, Paryżu i Berlinie w 16\%, ale większe jest zróżnicowanie wewnątrz mu- 
zułmanów aniżeli wśród Europejczyków. Najbardziej konserwatywną z badanych grup stanowią muzułmanie brytyjscy (poparcie tylko 4\%). Francuzi dwadzieścia razy częściej byli tolerancyjni w tej kwestii. Średnio Europejczycy są tolerancyjni dla homoseksualizmu ponad czterokrotnie częściej od zamieszkujących ich stolice muzułmanów. Religijni Amerykanie, z tolerancją w granicach $28 \%$, są znacznie bliżsi europejskim muzułmanom aniżeli Europejczykom. Jak widać, w kwestii homoseksualizmu obserwujemy dużą polaryzację poglądów moralnych.

Aborcję dopuszcza: 77\% Francuzów, 58\% Brytyjczyków, 52\% Niemców i $40 \%$ Amerykanów oraz $34 \%$ berlińskich muzułmanów, $24 \%$ paryskich muzułmanów, $10 \%$ londyńskich muzułmanów i $22 \%$ religijnych Amerykanów. Średni wynik akceptacji aborcji w trzech badanych grupach muzułmanów wynosi $22 \%$, czyli tyle, ile wynosi tolerancja w tym względzie religijnych Amerykanów. Obserwujemy znaczące dysproporcje wewnątrz badanych społeczeństw: największą różnicę znajdujemy w Wielkiej Brytanii - Brytyjczycy dopuszczają aborcję blisko sześć razy częściej niż londyńscy muzułmanie, Francuzi dopuszczają aborcję trzy razy częściej niż paryscy muzułmanie, a Niemcy tylko półtora raza częściej niż berlińscy muzułmanie. Badania pokazują istotne zróżnicowanie poglądów moralnych zarówno wśród europejskich muzułmanów: niemieccy muzułmanie trzyipółkrotnie częściej dopuszczają aborcję aniżeli brytyjscy muzułmanie, jak i w populacjach zachodnich: Francuzi blisko dwukrotnie częściej są tolerancyjni w kwestii aborcji aniżeli Amerykanie. Największy rozdźwięk spotykamy ponownie między Francuzami a brytyjskimi muzułmanami: ci pierwsi są blisko osiem razy częściej tolerancyjni w kwestii aborcji od muzułmanów z Londynu!

Akceptacja dla oglądania pornografii również różnicuje zachodnie społeczeństwa: Niemcy 60\%, Francuzi 52\% i Brytyjczycy $29 \%$ (Niemcy są dwa razy częściej tolerancyjni od Brytyjczyków), i społeczności muzułmańskie: berlińscy muzułmanie $24 \%$, paryscy muzułmanie $7 \%$ i londyńscy muzułmanie $4 \%$ (muzułmanie z Berlina są sześć razy częściej tolerancyjni od tych z Londynu). Średnio Niemcy, Francuzi i Brytyjczycy są tolerancyjni wobec oglądania pornografii $w 47 \%$, a europejscy muzułmanie w $11 \%$, a zatem Europejczycy średnio są ponad cztery razy częściej tolerancyjni od europejskich muzułmanów w kwestii oglądania pornografii.

W kwestii akceptacji dla przedmałżeńskiego seksu Zachód jest wyraźnie podzielony: badani Europejczycy są w tym względzie relatywnie częściej tolerancyjni aniżeli Amerykanie i religijni Amerykanie. Aż 88\% Francuzów, 86\% Niemców, 82\% Brytyjczyków oraz $61 \%$ Amerykanów i 38\% religijnych Amerykanów uważa, ze seks pozamałżeński jest moralnie akceptowalny. Także muzułmanie różnią się w poglądach na tę kwestię. Pozamałżeński seks akceptuje 38\% muzułmanów z Berlina, 30\% z Paryża i tylko 11\% z Londynu. O ile Europejczycy są w tej kwestii wyrównanie liberalni (od $82 \%$ do $88 \%$, średnio w $85 \%$ ), to europejscy muzułmanie trzy razy rzadziej są liberalni (średnio 26\%) i bardziej 
zróżnicowani poglądowo $\mathrm{w}$ tej kwestii (berlińscy muzułmanie są ponad trzy razy częściej liberalni od londyńskich). Charakterystyczne, że religijni Amerykanie plasują się na tym samym miejscu co muzułmanie z Berlina, przeciętni Amerykanie pośrodku: między tymi ostatnimi a Europejczykami, a Francuzi są osiem razy częściej tolerancyjni od muzułmanów z Londynu.

Przedstawione wyniki badań Instytutu Gallupa potwierdzają hipotezę Ingleharta o obyczajowym zderzeniu cywilizacji, a ponadto pokazują zróżnicowanie wewnątrz naszych cywilizacji. Zachód i muzułmanie mieszkający w Europie nie stoją konsekwentnie po dwóch stronach kulturowej barykady. Europejczycy i Amerykanie różnią się istotnie w moralnych poglądach. Przeciętni Amerykanie plasują się mniej więcej w połowie między Europejczykami a europejskimi muzułmanami, religijni Amerykanie zaś bliżsi są w swoim konserwatyzmie europejskim muzułmanom z Berlina aniżeli pozostałym Europejczykom. Muzułmanie są średnio trzy-cztery razy częściej konserwatywni od Europejczyków w badanych kwestiach moralnych. W społecznościach muzułmańskich także obserwujemy istotne zróżnicowanie wewnętrzne: najczęściej konserwatywni obyczajowo są muzułmanie z Londynu (islam azjatycki), najczęściej liberalni są muzułmanie z Berlina (zlaicyzowany islam turecki) — różnica między nimi jest cztero-sześciokrotna.

\section{MORALNOŚĆ NIE ZAWSZE DZIELI}

Ten sam sondaż Gallupa (przeprowadzony w trzech stolicach europejskich, w Paryżu, Berlinie i Londynie, oraz w Stanach Zjednoczonych w latach 2006 i 2007) pokazał, że nie wszystkie kwestie moralne dzielą (Rheault, Mogahed 2008a). Europejczycy i muzułmanie mają zbliżone zdanie w trzech ważnych kwestiach moralno-prawnych: honorowe zabójstwa (obyczaj kojarzony z muzułmańską społecznością), zbrodnie w afekcie namiętności (przestępstwo neutralne kulturowo) i kara śmierci. W kwestii zabójstw honorowych (zabójstw dokonanych przez mężczyzn na spokrewnionych kobietach, którym zarzuca się splamienie honoru rodziny) Europejczycy i ich muzułmańscy sąsiedzi są zgodni: tylko 1\% Niemców i Brytyjczyków oraz 4\% Francuzów uznało je za moralnie akceptowalne $\mathrm{w}$ porównaniu do $3 \%$ muzułmanów mieszkających $\mathrm{w}$ Berlinie i Londynie oraz 5\% paryskich muzułmanów. Zważywszy na małe różnice procentowe wyników i fakt, że margines błędu w tych badaniach waha się od 3-5\%, nie ma sensu porównywać tych informacji.

Ciekawe i nieprzypadkowe jest zestawienie badań nad akceptacją zabójstw honorowych z zabójstwami dokonanymi w afekcie — w jednych i drugich mamy do czynienia $z$ seksualnym kontekstem i wzburzeniem emocjonalnym, tylko pierwsze jednak mają uzasadnienie kulturowe. Zabójstwa z namiętności dopuszcza moralnie 2\% Brytyjczyków, 1\% Niemców i aż 8\% Francuzów oraz 1\% muzułmanów w Berlinie, 3\% w Londynie i 4\% w Paryżu. Dlaczego francuska opinia publiczna jest bardziej tolerancyjna dla zbrodni z namiętności niż 
reszta Europejczyków i muzułmanie? Zapewne jednym z powodów jest fakt, że jeszcze trzydzieści lat temu francuskie prawo dopuszczało lżejszą karę, jeśli mężczyzna zabił swoją żonę lub bliską partnerkę po odkryciu seksualnej zdrady. Chociaż przepisy prawa karnego zmieniły się w 1975 r., obserwatorzy odnotowują, że Francuzi wciąż mają tendencję do oceniania takich zbrodni i skazanych za nie z pobłażaniem.

W kwestii kary śmierci poglądy Europejczyków i muzułmanów różnią się wyraźniej, chociaż obie grupy pozostają w tyle za najbardziej konserwatywnymi Amerykanami, którzy dopuszczają karę śmierci w 62\% (religijni Amerykanie w 59\%). Muzułmanie berlińscy i paryscy mają takie same poglądy (19\%), opinia niemiecka zbliżone (22\%). Większe przyzwolenie na karę śmierci obserwujemy wśród muzułmanów londyńskich (31\%), a jeszcze większe w opinii francuskiej (39\%) i brytyjskiej (43\%). Kara śmierci jest blisko dwukrotnie częściej akceptowana przez Europejczyków i trzykrotnie częściej przez Amerykanów niż przez europejskich muzułmanów. W tej kwestii Amerykanie przyjmują rolę fundamentalistów kulturowych.

Wyniki sondażu Gallupa pokazują, że są kwestie moralne, w których Europejczycy i europejscy muzułmanie przemawiają jednym głosem: zabójstwa honorowe i zbrodnie w afekcie namiętności. Niestety cytowany sondaż Gallupa, podobnie jak Światowy Sondaż Wartości bada tylko przekonania. Tymczasem dla badań nad procesem integracji kulturowej ważne są rzeczywiste zachowania wynikające $z$ przekonań. Brak akceptacji dla wolności osobistej córek może oznaczać problem $z$ integracją zachodnich muzułmanów, ale nie musi. Problem zaczyna się wtedy, kiedy powodowani swoimi przekonaniami muzułmańscy rodzice ograniczają prawo córek do wychodzenia $z$ domu, spotykania się z rówieśnikami, podejmowania studiów i pracy, w końcu wydają swoje córki za mąż wbrew ich woli. Wtedy odmawiają swoim córkom swobód demokratycznych przysługujących wszystkim obywatelom europejskich ojczyzn.

\section{NADZIEJA W DEMOKRACJI?}

Optymistyczne wyniki badań Światowego Sondażu Wartości każą ufać w atrakcyjność i popularność idei demokracji. Ale jak pogodzić ten optymizm z powrotem islamu do rządów wielu krajów muzułmańskich? W wyniku demokratycznych wyborów partie islamistyczne w różnym stopniu zdobyły ostatnio władzę polityczną w Turcji, Egipcie, Libanie, na okupowanych terytoriach Palestyny, poszerzają swoje wpływy w Maroku i Jordanie. W tej sytuacji powraca pytanie: czy islam pozostaje $\mathrm{w}$ zgodzie $\mathrm{z}$ demokracją?

Badanie Instytutu Gallupa z 2006 r. (Mogahed 2006) przeprowadzone w dziesięciu muzułmańskich krajach, w których żyje $80 \%$ światowej populacji muzułmanów, rzuca nowe światło na ten problem. Z sondażu wynika, że muzułmanie podziwiają na Zachodzie przede wszystkim wolność polityczną, wolność jako taką, sprawiedliwy system sądowniczy i wolność słowa. Znacząca 
większość we wszystkich badanych krajach - 99\% w Libanie, 94\% w Egipcie, 92\% w Iranie, 91\% w Maroku, 88\% w Turcji, 87\% w Bangladeszu, 86\% w Indonezji, $84 \%$ w Jordanii i $82 \%$ w Pakistanie ${ }^{6}$ - w projektowanej przez siebie konstytucji zagwarantowałaby wolność słowa, rozumianą jako „zezwolenie wszystkim obywatelom na wyrażanie swoich opinii na tematy polityczne, społeczne i ekonomiczne". Zanotowano także silne poparcie dla wolności religii i wolności zgromadzeń.

Jednocześnie pytani o krytykę ich własnych społeczeństw muzułmanie wymieniają przede wszystkim ekstremizm i nieprzestrzeganie zasad islamu. A to oznacza, że choć podziwiają zachodnią wolność i otwarty system polityczny, nie dopuszczają konieczności wyboru między islamem a demokracją. Jak pokazuje kolejny sondaż, ufają raczej, że islam i demokracja dają się pogodzić w jednym systemie rządzenia. Badani w większości deklarowali oparcie prawodawstwa na szariacie - prawie religijnym. Problem w tym, że w szariacie źródłem prawa jest sam Bóg (głównym jego filarem jest święty Koran), a więc człowiekowi nie wolno go zmieniać, podczas gdy europejska tradycja opiera się na rzymskim prawie stanowionym przez ludzi i przez nich zmienianym. Przypomnijmy, że szariat reguluje całe życie człowieka, obejmuje nie tylko kwestie kultu, ale także te dotyczące ogółu stosunków międzyludzkich, funkcjonowania społeczności muzułmańskiej, a przede wszystkim rodziny.

Sondaż Gallupa pokazuje, że blisko 80\% muzułmanów w badanych dziesięciu krajach muzułmańskich wprowadziłoby szariat jako przynajmniej jeden z filarów legislacji. W pięciu krajach tylko mniejszość widziała szariat jako „jedyne źródło" prawa (Liban 8\%, Turcja 9\%, Iran 13\%, Indonezja 14\%, Maroko $33 \%)$. Jednakże dla większości ,jedynym źródłem” prawodawstwa szariat był w Egipcie (66\%), Pakistanie (60\%), Jordanii (54\%) i Bangladeszu (52\%). Wyjątek stanowi Turcja, gdzie $57 \%$ powiedziało, że szariat nie powinien być źródłem legislacji, ale konstytucja tego kraju wyraźnie odgranicza religię od sfery rządzenia. Takie wyniki badań mogą wprawiać Zachód w konsternację, gdyż szariat jest u nas często utożsamiany ze zbiorem opresywnych praw, takich jak kamienowanie za cudzołóstwo, obcinanie kończyn za kradzież czy więzienie lub śmierć za apostazję.

Wyjaśnienia tego zaskakującego poparcia dla demokracji i szariatu jednocześnie należy poszukiwać $\mathrm{w}$ odmiennym postrzeganiu szariatu w świecie zachodnim i muzułmańskim. Potwierdzają to badania przeprowadzone przez Gallup Poll w trzech politycznie odmiennych krajach muzułmańskich: Egipcie, Iranie i Turcji. Pozytywne skojarzenia z szariatem istotnie przewyższały tam te negatywne. Na przykład ze stwierdzeniem, że szariat gwarantuje sprawiedliwość dla kobiet, zgodziło się 76\% Irańczyków, 97\% Egipcjan, 69\% Turków. Ze stwier-

\footnotetext{
${ }^{6}$ Pytanie o zagwarantowanie wolności słowa w konstytucji nie zostało zadane w Arabii Saudyjskiej.
} 
dzeniem, że szariat chroni prawa człowieka, zgodziło się 76\% Irańczyków, 97\% Egipcjan i $62 \%$ Turków. Ze stwierdzeniem, że szariat promuje sprawiedliwy system sądowniczy, zgodziło się 80\% Irańczyków, 96\% Egipcjan, 63\% Turków.

Tak wysoka ocena szariatu w badanych trzech krajach skłania do postawienia kilku hipotez. Jeżeli w każdym $z$ badanych krajów inaczej interpretuje się szariat, porównujemy nie stosunek do szariatu, lecz różne o nim wyobrażenia związane ze stopniem religijności i wiedzą religijną. Taką hipotezę wydają się potwierdzać nieliczne złe skojarzenia z szariatem. Na przykład aż 69\% Egipcjan i tylko 33\% Turków kojarzy szariat z surowymi karami za przestępstwa kryminalne. W takiej sytuacji metodologicznie lepszym posunięciem byłyby pytania o poparcie dla konkretnych praw szariatu, tak jak pytano o konkretne wolności demokratyczne.

Inne badanie pokazuje, że poparcie dla szariatu nie oznacza bynajmniej wyboru teokracji (Mogahed 2006). Tylko mniejszość w każdym z badanych krajów opowiedziała się za bezpośrednim wpływem przywódców religijnych na konstytucję, narodowe prawodawstwo, politykę zagraniczną, kobiecy strój w przestrzeni publicznej, a także to, co drukują gazety i pokazuje telewizja (Liban 14\%, Turcja 16\%, Maroko 16\%, Bangladesz 19\%, Indonezja 24\%, Iran $26 \%$, Pakistan 33\%, Jordania 39\%).

Duże poparcie dla szariatu jako co najmniej jednego ze źródeł legislacji jest także konsekwencją popularnego poglądu, że religia powinna odgrywać dużą rolę w życiu muzułmanów: 98\% muzułmanów w Egipcie, 99\% w Indonezji i $86 \%$ w Turcji powiedziało, że religia jest ważną częścią ich życia codziennego. Poproszeni o nazwanie własnymi słowami tego, co najbardziej cenią w arabskim/muzułmańskim świecie, muzułmańscy respondenci najczęściej udzielali odpowiedzi: „wierność islamskim wartościom”. Przypomnijmy, że w tym samym czasie najwyżej oceniane przez nich na Zachodzie są „wolność jako taka i wolność słowa”. Paradoks ten można wytłumaczyć tym, że za podziwem dla zachodnich wolności politycznych nie idzie entuzjazm dla zachodnich obyczajów. Muzułmanie nie aprobują zachodniej rozwiązłości seksualnej i moralnej dekadencji. Mówią zatem „tak” demokracji, ale „nie” liberalizmowi wykraczającemu poza sferę wolności politycznych. Pożądany przez muzułmanów model rządzenia stanowiłby połączenie demokratycznego ustroju z islamskimi zasadami obyczajowości ${ }^{7}$. Ten na pozór sprzeczny model łączący demokrację liberalną z dużą religijnością obywateli odnajdujemy w Stanach Zjednoczonych. A i w Polsce, gdybyśmy zapytali zwykłych obywateli, czy chcieliby, aby kon-

7 Sondaż ten pokazał także zależność między poparciem dla szariatu a wiekiem i poziomem wykształcenia. Zgodnie z oczekiwaniami - starsi respondenci chętniej niż młodzi, a gorzej wyedukowani chętniej niż lepiej wyedukowani uznaliby szariat jako jedyne źródło prawodawstwa. Co nie zmienia faktu, że bez względu na wiek i wykształcenie większość Irańczyków i Egipcjan opowiedziała się za wpływem prawa religijnego na prawodawstwo. Zarówno Irańczycy, Egipcjanie, jak i Turcy wierzą, że religia i władza mogą być zintegrowane. 
stytucja państwa była oparta na dekalogu, zapewne otrzymalibyśmy deklarację wysokiego poparcia dla takiego rozwiązania.

\section{RZECZYWISTY KONFLIKT: MODERNIZM KONTRA FUNDAMENTALIZM}

Do tej pory zidentyfikowaliśmy już różnice kulturowe odpowiedzialne za konflikt międzykulturowy, a teraz wypada się upewnić, kto stoi po obu stronach barykady. Czy jest tak, jak sugerował Huntington, że mamy zderzenie między cywilizacją islamu a Zachodem? A może religijny islam zderza się ze zlaicyzowaną Europą? Główny konflikt rozgrywa się między europejskimi muzułmanami a rdzennymi Europejczykami czy też linia frontu kulturowego przebiega w poprzek społeczności muzułmańskich? W końcu — jaki jest układ sił po obu stronach kulturowej barykady?

Zamachy terrorystyczne ostatnich lat rozpętały tak wielką burzę medialną ${ }^{8}$, że dziś patrzymy na przeciętnych muzułmanów jak na potencjalnych terrorystów, zapominając, że większość z nich nie tylko nie ma $\mathrm{z}$ terroryzmem nic wspólnego, ale potępia go tak samo jak Zachód.

Publikacja Johna L. Esposito i Dalii Mogahed (2008), w której tytule autorzy postawili pytanie: Kto mówi w imieniu islamu?, traktuje o tej „milczącej”, „niemedialnej” większości przebadanej w ramach szeroko zakrojonych, wieloletnich badań Gallup World Poll. W latach 2001, 2005-2007 przeprowadzono wywiady z 10000 respondentów z ponad 35 krajów z przewagą społeczności muzułmańskiej lub znacznym jej udziałem (ogółem badania reprezentują ponad $90 \%$ muzułmanów na świecie). Zadano pytania, które nurtują dzisiaj wszystkich: Czy islam jest ślepy na terroryzm? Dlaczego jest tyle antyamerykanizmu w świecie muzułmańskim? Kim są ekstremiści? Gdzie są umiarkowani muzułmanie? Czego faktycznie chcą muzułmańskie kobiety? Dane z sondażu Gallupa dają nam wyobrażenie o rzeszy muzułmanów - o przeciętnych ludziach, a nie o ekstremistach. Dowiadujemy się z nich, że:

— muzułmanie nie postrzegają Zachodu monolitycznie, krytykują lub podziwiają poszczególne kraje za ich politykę — nie kulturę lub religię (to fundamentaliści podtrzymują dyskurs o zderzeniu cywilizacji!);

- proszeni o opisanie marzeń na przyszłość, nie wspominają o dżihadzie, lecz o lepszej pracy;

- muzułmanie i Amerykanie w równym stopniu odrzucają ataki na ludność cywilną jako moralnie nieusprawiedliwione;

— ci, którzy dopuszczają akty terroryzmu, są w mniejszości i nie są bardziej religijni niż reszta populacji;

- muzułmanie na całym świecie najbardziej podziwiają na Zachodzie technologię i demokrację (takiej samej odpowiedzi udzielili Amerykanie!);

8 Słynna hipoteza Huntingtona o zderzeniu cywilizacji zdobyła popularność w dużej mierze za sprawą mediów. 
— muzułmanie na całym świecie krytykują Zachód za jego moralne zepsucie (upadek) i rozkład tradycyjnych wartości (takiej samej odpowiedzi udzielili Amerykanie!);

— muzułmanki chcą równych praw, ale i religii w swoich społeczeństwach;

- muzułmanie na całym świecie powiedzieli, że tym, co może zrobić Zachód, żeby poprawić swoje relacje $z$ ich społeczeństwami, jest złagodzenie swoich poglądów na temat muzułmanów i szacunek dla islamu;

- większość badanych chce, aby przywódcy religijni nie odgrywali bezpośredniej roli $\mathrm{w}$ tworzeniu konstytucji, faworyzują jednak religijne prawo jako źródło legislacji.

Z przytoczonych badań można wysnuć kilka interesujących wniosków. Jeżeli najbardziej różni nas religijność i liberalizacja obyczajowa, to największy antagonizm rysuje się między islamem a Europą, a nie islamem a Zachodem. Przeciętni muzułmanie mają, paradoksalnie, wiele wspólnego z większością Amerykanów, którzy chętnie widzieliby Biblię jako źródło legislacji, przywiązują dużą wagę do rodzinnych wartości i są głęboko zaniepokojeni upadkiem moralności. Dlaczego więc jest tyle antyamerykanizmu w świecie muzułmańskim? Skoro nie mamy do czynienia ze zderzeniem cywilizacji, co sugerują przytaczane badania, chodzi tu raczej o konflikt polityczny. Do grzechów politycznych Stanów Zjednoczonych, które wygenerowały nienawiść do świata muzułmańskiego, z pewnością należą: imperialny kolonializm, konflikt palestyńsko-żydowski i jednoznaczne poparcie Stanów Zjednoczonych dla Izraela po 1967 r., „pokojowa okupacja” Arabii Saudyjskiej (ropa!), dwulicowość, czyli poparcie udzielane despotom sprzyjającym interesom Zachodu (ropa!) mimo oficjalnych deklaracji o dążeniu do zaprowadzenia demokracji na Bliskim Wschodzie, w końcu interwencja zbrojna w Afganistanie i Iraku.

Hipoteza o zderzeniu cywilizacji jest często mitologizowana i przez obie strony wykorzystywana instrumentalnie w ideologicznej konfrontacji. Sięgają po nią zarówno zachodni prawicowi populiści (np. Jean-Marie Le Pen we Francji), którzy zbijają kapitał polityczny na społecznej niechęci do obcych, jak i islamscy fundamentaliści, dla których pojęcie „wojny z Zachodem” ma cenną moc jednoczenia zwaśnionego świata muzułmańskiego rozdartego między tęsknotą za świetlaną przeszłością a reformatorskimi wizjami przyszłości. Trzeba jednak zauważyć, że w tej ideologicznej konfrontacji Zachód stanowi dla muzułmanów ambiwalentny punkt odniesienia. Nienawidzony za polityczny imperializm, jest jednocześnie obiektem podziwu i zazdrości ze względu na system demokratyczny, postęp techniczny i sukces gospodarczy. Z kolei współczesna kultura zachodnia jest odrzucana i demonizowana przez fundamentalistów lub przejmowana (w różnym zakresie) przez muzułmanów upatrujących $\mathrm{w}$ niej wzór nowoczesności.

Współczesne zderzenie cywilizacji, rozumiane jako zderzenie niekompatybilnych systemów wartości, norm i obyczajów, zachodzi dziś nie na linii Zachód-Islam, lecz na linii nowoczesność-konserwatyzm/fundamentalizm. Do 
konfliktów na tej linii dochodzi przede wszystkim w świecie islamu, ale także w społeczeństwach zachodnich ${ }^{9}$. Mamy więc nie tylko międzycywilizacyjny, ale i wewnątrzkulturowy konflikt wartości. Rozłam dotyczy zarówno muzułmańskich ojczyzn, jak i społeczności imigracyjnych. Mieszkańcy krajów o przewadze muzułmańskiej dostrzegają w swych społeczeństwach konflikt między dwiema wizjami przyszłości: fundamentalistyczną (islamem ortodoksyjnym) i modernistyczną (islamem nowoczesnym). Co więcej, z każdym rokiem konflikt ten staje się coraz wyraźniejszy.

Wykres 2

Muzułmanie dostrzegający konflikt między modernistami a fundamentalistami (w \%)

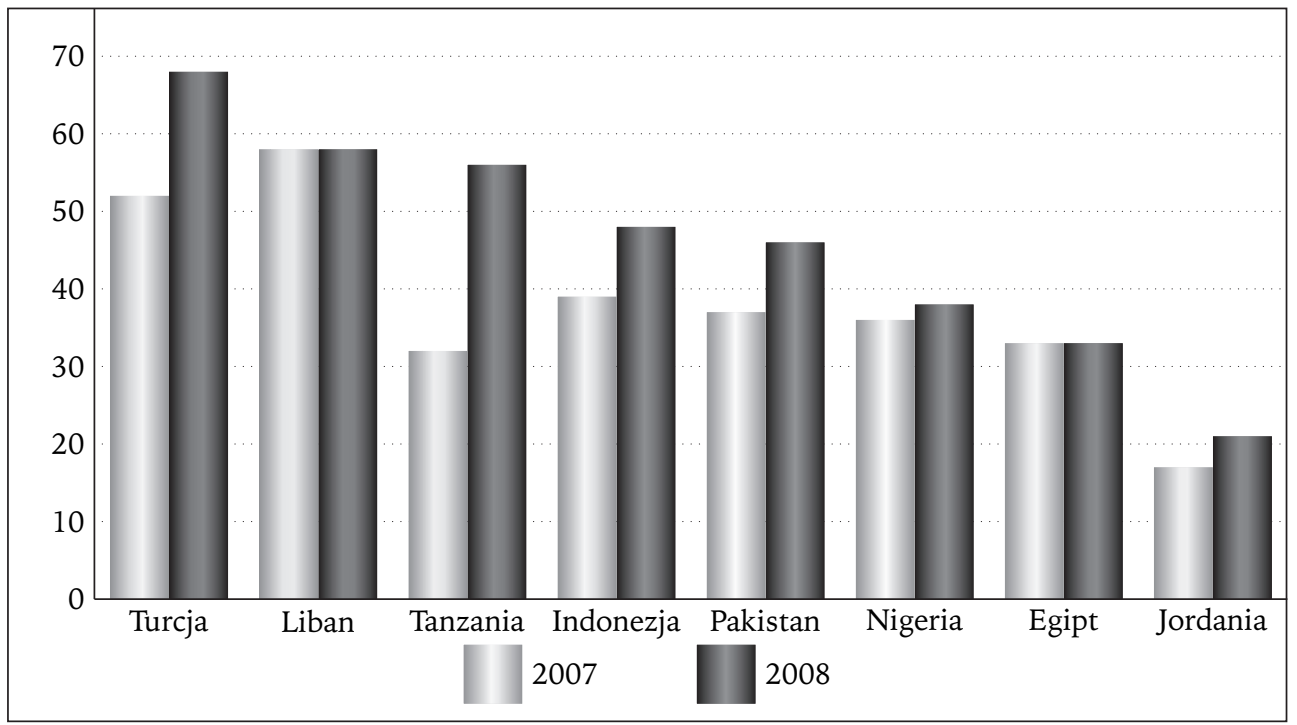

Źródło: PGAP 2008.

Także muzułmanie mieszkający we Francji, Wielkiej Brytanii, Niemczech i Hiszpanii dostrzegają konflikt między umiarkowanym i fundamentalnym islamem (PGAP 2006). Optymizmem napawa jednak fakt, że we wszystkich wymienionych krajach większość muzułmanów identyfikuje się z umiarkowanym islamem.

Konflikty międzykulturowy i wewnątrzkulturowy są ze sobą sprzężone. Punktem odniesienia dla muzułmańskich modernistów jest świat zachodni, więc fundamentaliści islamscy walczą zarówno z kulturą Zachodu, jak i jej muzułmańskimi zwolennikami.

\footnotetext{
9 Jeżeli można zaliczyć Polskę do krajów Zachodu, to przykładem takiego konfliktu są polskie parady równości.
} 
Muzułmanie europejscy a konflikt wewnątrzkulturowy (w \%)

\begin{tabular}{|l|c|c|c|}
\hline \multicolumn{1}{|c|}{ Kraj } & $\begin{array}{c}\text { Muzułmanie } \\
\text { dostrzegający konflikt }\end{array}$ & $\begin{array}{c}\text { Muzułmanie } \\
\text { identyfikujący się } \\
\text { z umiarkowanymi }\end{array}$ & $\begin{array}{c}\text { Muzułmanie } \\
\text { identyfikujący się } \\
\text { z fundamentalistami }\end{array}$ \\
\hline Wielka Brytania & 58 & 38 & 15 \\
Francja & 56 & 50 & 6 \\
Niemcy & 49 & 36 & 7 \\
Hiszpania & 21 & 14 & 4 \\
\hline
\end{tabular}

Źródło: PGAP (Kohut 2006).

„W dużym stopniu — jak prognozuje Gilles Kepel (2006, s. 294) — bitwa o przyszłość islamu - między nowoczesnością a konserwatyzmem, laicyzacją życia a ekspansją fundamentalizmu — rozegra się w Europie, wśród żyjących tu milionów muzułmanów. Islam europejski stanowi dzisiaj awangardę tej bitwy, wzorzec, na którym skupiają się spojrzenia muzułmanów z całego świata, pragnących żyć bez jarzma autorytarnych reżimów oraz krwawych urojeń bojowników dżihadu".

Zamiast ukutego przez Huntingtona pojęcia „zderzenie cywilizacji”, które jest konfliktogenne (chętnie powołują się na nie i zachodni populiści, i bojownicy dżihadu) i nadmiernie uogólniające, proponuję mówić o konflikcie wartości w świecie wielokulturowym. W wyniku interakcji z kulturą zachodnią także tradycyjne dotychczas społeczeństwa muzułmańskie na Bliskim Wschodzie i w Afryce Północnej zaczynają być wielokulturowe, opowiadając się za różnymi, czasami niekompatybilnymi systemami wartości i norm. Nowoczesność lub konserwatyzm muzułmanów często są skorelowane z miejscem zamieszkania: miastem lub wsią.

Między skrajnym modernizmem a fundamentalizmem rozpościera się szeroka gama religijności: zabarwionych etnicznie, czerpiących z różnych szkół koranicznych, interpretowanych indywidualnie, mniej lub bardziej zlaicyzowanych ${ }^{10}$. Cytowane badania sugerują, że wielu muzułmanów widzi w islamie coś więcej niż religię — znak tożsamości, źródło znaczenia, przewodnictwa, konsolidacji i wspólnotowości. Dla wielu muzułmanów jest to duchowo-mentalna mapa, oferująca sens znaczeń, kierunek, cel i nadzieję. Znaczenie religii jest wzmocnione przez tradycję i obyczaje, które także odgrywają centralną rolę w życiu muzułmanów. Na pytanie: „Czy są tradycje i obyczaje, które są dla Ciebie ważne?” (Esposito, Mogahed 2008), większość odpowiedziała „tak”: Jordańczycy 96\%, Saudyjczycy 95\%, Turcy 90\%, Egipcjanie $87 \%$. $\mathrm{Na}$ to samo pytanie tylko $54 \%$ Amerykanów odpowiedziało pozytywnie, jeszcze mniej Europejczyków: Wielka Brytania 36\%, Francja 20\%, Belgia 23\%.

$10 \mathrm{~W}$ islamie nie istnieje pojęcie „wierzący niepraktykujący”, ale takich muzułmanów z dnia na dzień przybywa - wystarczy oszacować frekwencję wiernych w meczetach. 
Wbrew potocznym wyobrażeniom islam nie jest dla swoich wiernych skostniałym zbiorem reguł i kar. Nawet dla muzułmanów niepraktykujących islam stanowi istotny element tożsamości - często jest to jedyne kulturowe i symboliczne dobro, które mogą przedstawić rdzennym Europejczykom z pochodzenia, umożliwiające im przekształcenie wykluczenia w dobrowolną różnicę. A to oznacza, że integracja europejskich muzułmanów będzie oparta na szeroko rozumianym islamie. Modernizm w obrębie świata islamu nie oznacza jego pełnej laicyzacji, chodzi raczej o nowoczesną interpretację i lepiej przystającą do nowoczesności formułę islamu.

\section{KULTURA NAJMNIEJSZYM ZMARTWIENIEM EUROPEJSKICH MUZUŁMANÓW?}

Wyniki badań Pew Global Attitudes Survey (wiosna 2006) nad muzułmanami żyjącymi w czterech krajach europejskich: we Francji, Wielkiej Brytanii, Niemczech i Hiszpanii osłabiają, jak można sądzić, słynną tezę Samuela Huntingtona o nieuchronnym zderzeniu cywilizacji — pokazują bowiem, że europejskim muzułmanom bardziej doskwiera problem bezrobocia aniżeli dekadencka kultura zachodnia czy nowoczesne role kobiet.

Tablica 3

Muzułmanie zaniepokojeni bezrobociem oraz religijnymi i kulturowymi kwestiami (w \%)

\begin{tabular}{|l|c|c|c|c|}
\hline \multirow{2}{*}{ Przyczyna niepokoju } & \multicolumn{4}{|c|}{ Muzułmanie w ... } \\
\cline { 2 - 5 } & Wielkiej Brytanii & Francji & Niemczech & Hiszpanii \\
\hline Bezrobocie & 46 & 52 & 56 & 55 \\
Islamski ekstremizm & 44 & 30 & 23 & 22 \\
Upadek religii & 45 & 21 & 18 & 18 \\
Wpływ pop-kultury & 44 & 17 & 18 & 17 \\
Nowoczesne role kobiet & 22 & 16 & 9 & 10 \\
\hline
\end{tabular}

Źródło: PGAP 2006.

Muzułmanie z czterech badanych krajów podzielają w większości opinię na temat jakości życia w nowych europejskich ojczyznach. Wszyscy zgodnie wskazują na czynnik ekonomiczny jako główną barierę integracji. Duże zaniepokojenie bezrobociem wyraża ponad połowa $(52 \%)$ francuskich muzułmanów ${ }^{11}$, a $32 \%$ martwi to w nieco mniejszym stopniu, co daje w sumie $84 \%$. Podobne wyniki uzyskano w Hiszpanii (83\%), Niemczech (81\%) i - nieco tylko odbiegające - w Wielkiej Brytanii (78\%). We wszystkich czterech przebadanych krajach bezrobocie bardziej martwi muzułmanów aniżeli islamski ekstremizm, upadek religii (zanik religijności), wpływ popkultury czy nowoczesne

\footnotetext{
11 Przypomnijmy, że właśnie czynnik ekonomiczny był główną przyczyną wybuchu zamieszek w $2005 \mathrm{r}$.
} 
role kobiet. Przy czym muzułmanie mieszkający w Wielkiej Brytanii są wyraźnie bardziej zmartwieni wszystkimi wymienionymi czynnikami aniżeli ich bracia $w$ wierze $z$ pozostałych trzech krajów.

Czy cytowane badania dowodzą, że kultura ma mniejsze znaczenie niż przewidywał Huntington? I tak, i nie. Czynnik ekonomiczny wydaje się decydujący podwójnie: przesądza o integracji ekonomicznej, ale pośrednio także o integracji kulturowej. Brak pieniędzy, życie na garnuszku państwa w połączeniu z poczuciem dyskryminacji upokarza. Upokorzenie rodzi frustrację, agresję i mechanizmy obronne. Jednym $z$ nich jest budowa tożsamości grupowej w opozycji do społeczeństwa „nieprzyjmującego” — przez reaktywację kultury rodzimej, często w wersji ortodoksyjnej. W ten sposób kryzys ekonomiczny prowokuje i wzmacnia konserwatyzm kulturowy. Mechanizm ten można było zaobserwować na imigranckich przedmieściach Francji dużo wcześniej zanim świat poruszyły wiadomości o samochodach płonących tam podczas zamieszek w listopadzie 2005 r. i 2006 r.).

Jeszcze w latach siedemdziesiątych znaczna część imigracji muzułmańskiej akceptowała europejski system społeczny, byli to ludzie religijnie umiarkowani lub wręcz obojętni. Część z nich przybyła ze swych arabskich i muzułmańskich ojczyzn do Europy, by żyć właśnie w takiej zachodniej, otwartej kulturze. Jednak mniej więcej od dwudziestu lat sytuacja się zmienia (przypomnijmy, że pierwszy przypadek sporu o chustę odnotowano we Francji w 1989 r.) i asymilacja zaczęła tracić na atrakcyjności. Współczesne, trzecie już pokolenie imigrantów z Maroka, Algierii, Tunezji i Turcji, zmagające się z bezrobociem, jest zbuntowane, wyobcowane, coraz bardziej otwarte na wspólnotowy urok radykalnego islamu. Powszechne jest teraz podkreślanie własnej tożsamości, nawracanie się na islam i opór wobec asymilacji. Sondaże Francuskiego Instytutu Badania Opinii Publicznej (IFOP 2001) pokazały, że identyfikacja z islamem w $2001 \mathrm{r}$. wzrosła w porównaniu z rokiem 1994 lub 1989 (w 1994 r. 27\% badanych deklarowało się jako „wierzący i praktykujący”, a w 2001 r. było ich już 36\%).

Przeprowadzone wiosną 2006 r. badania PGAP potwierdzają tendencję wzrostową identyfikacji z islamem. Francuscy muzułmanie pytani, czy w pierwszej kolejności uważają się za obywateli swojego kraju, czy za wyznawców islamu, podzielili się na dwie, porównywalne co do wielkości grupy: $42 \%$ do $46 \%$. W grupie powyżej 35 roku życia $45 \%$ francuskich muzułmanów na pierwszym miejscu stawia tożsamość narodową, a $36 \%$ - religijną, dla $16 \%$ członków tej grupy obydwie tożsamości są tak samo ważne. W grupie do 35 roku życia (wiele osób jest Francuzami z urodzenia) $40 \%$ uważa się przede wszystkim za Francuzów, $51 \%$ za muzułmanów, a $7 \%$ traktuje obie te tożsamości na równi. Mamy zatem do czynienia ze wzrostem poczucia tożsamości muzułmańskiej wśród młodych francuskich muzułmanów.

Te same badania pokazały, że większość francuskich muzułmanów (57\%) w jakimś stopniu przejmuje się malejącą rolą religii we Francji, a (38\%) wyraża niepokój o przyszłość swoich współwyznawców we Francji. Jednak naj- 
większym problemem francuskich muzułmanów jest w 2006 r. bezrobocie. Duże nim zaniepokojenie wyraża ponad połowa $(52 \%)$ francuskich muzułmanów, a $32 \%$ nieco mniejsze, co daje w sumie $84 \%$ (przypomnijmy, że to właśnie trudna sytuacja ekonomiczna była główną przyczyną wybuchu zamieszek w 2005 r.).

Tym, co najbardziej wyróżnia francuskich muzułmanów wśród wyznawców islamu żyjących w Europie, jest sposób, w jaki postrzegają samych siebie. Aż siedmiu na dziesięciu (72\%) francuskich muzułmanów w ogóle nie odczuwa konfliktu między byciem osobą głęboko wierzącą a życiem w nowoczesnym społeczeństwie (dla porównania w Wielkiej Brytanii zdania są podzielone $47 \%$ widzi konflikt, 49\% nie). Kolejne pytanie częściowo rozjaśnia tę zagadkę i jednocześnie napawa pewną nadzieją. Aż 78\% francuskich muzułmanów chce przyjąć obyczaje francuskie (alternatywą było odróżnianie się od francuskiego społeczeństwa). Tym razem osoby poniżej 35 roku życia mają takie samo zdanie jak starsi. Dla porównania asymilacji chce $53 \%$ populacji muzułmańskiej w Hiszpanii, 41\% w Wielkiej Brytanii i 30\% Niemczech.

Badania PGAP z 2006 r. odzwierciedlają opisywany wcześniej ambiwalentny stosunek muzułmanów do świata zachodniego. Odmienność postaw w grupach do 35 roku życia i powyżej w zakresie odczuwanej tożsamości pokazuje, że integracja muzułmańskich imigrantów została zahamowana. Islam znowu jawi się jako źródło sensu, siły, tożsamości, nadziei i stabilności. Z kolei brak odczucia konfliktu pomiędzy byciem osobą głęboko wierzącą a życiem w nowoczesnym społeczeństwie wskazuje na duży stopień laicyzacji francuskich imigrantów i ogromną chęć integracji, której przeszkadza rasizm i dyskryminacja ze strony Francuzów. Historia imigranckich przedmieść Francji dobrze obrazuje ten proces.

Czynnikiem zapalnym zamieszek na przedmieściach Francji w listopadzie 2005 r. i rok później („w rocznicę” zamieszek) nie było zderzenie kultur, lecz ekonomiczno-społeczne wykluczenie imigrantów przez społeczeństwo przyjmujące. Zamieszki były rozpaczliwym poszukiwaniem sensu, tożsamości, dowartościowania. Konflikt międzykulkturowy był raczej efektem ubocznym nieudanego procesu integracji aniżeli jego główną przyczyną.

\section{BIBLIOGRAFIA}

Bourdieu Pierre, 1991, Préface, w: Abdelmalek Sayad, L'immigration ou les paradoxes de l'altérité, De Boeck Université, Bruxelles.

Bujis Frank J., Rath Jan, 2002, Muslim in Europe: The State for Research, Russell Sage Foundation, New York.

Cesari Jocelyne, 1994, Etre musulman en France, Karthala-Iremam, Paris-Aix-en-Provence. Esposito John L., Mogahed Dalia, 2008, Who Speaks for Islam? What a Billion Muslims Really Think, Gallup Press, New York.

Harrison Lawrence E., Huntington Samuel P. (red.), 2003, Kultura ma znaczenie. Jak wartości wpływają na rozwój społeczeństw, tłum. Sławomir Dymczyk, Zysk i S-ka, Poznań. 
Huntington Samuel P., 2001 [1996], Zderzenie cywilizacji, tłum. Hanna Jankowska, Muza, Warszawa.

IFOP, 2001, The Situaton of Muslim in France, Paris.

Inglehart Ronald, Norris Pippa, 2003a, Rising Tide: Gender Equality and Cultural Change around the World, Cambridge University Press, Cambridge.

Inglehart Ronald, Norris Pippa, 2003b, The True Clash of Civilizations, „Foreign Policy”, nr 135, s. 62-70.

Inglehart Ronald, Norris Pippa, 2009, Muslim Integration into Western Cultures: Between Origins and Destinations (http://ksghome.harvard.edu/ pnorris/Acrobat/Muslim\%20 Integration\%20Into\%20Western\%20Societies.pdf).

Inglehart Ronald, Welzel Christian, 2005, Modernization, Cultural Change and Democracy: The Human Development Sequence, Cambridge University Press, New York.

Jones Trevor, 1993, Britain's Ethnic Minority, Policy Studies Institute, London.

Kepel Gilles, 2006, Fitna. Wojna w sercu islamu, tłum. Katarzyna Pachniak, Dialog, Warszawa.

Kohut Andrew, 2006, Islam and the West: Searching for Common Ground, Pew Global Attitudes Project (http://pewglobal.org/2006/07/18/islam-and-the-west-searching-for-common-ground).

Modood Tariq, Berthoud Richard, 1997, Ethnic Minorities in Britain - Diversity and Disadvantage, Policy Studies Institute, London.

Mogahed Dalia, 2005, Perspectives of Women in the Muslim World, Gallup Center for Muslim Studies (http://www.muslimwestfacts.com/mwf/105673/Perspectives-Women-Muslim-World.aspx).

Mogahed Dalia, 2006, Islam and Democracy: Muslim World Residents See No Conflict between Religious Principles and Democratic Values, Gallup Center for Muslim Studies (http://www.muslimwestfacts.com/mwf/105643/Islam-Democracy.aspx).

Pasamonik Barbara, 2006a, Problem with Islam? Gender, Sex and Clash of Civilizations, „The International Affairs Review", nr 1.

Pasamonik Barbara, 2006b, Integracja bez asymilacji? Zderzenie Islamu $i$ Zachodu $w$ Europie, w: Obywatelstwo $i$ tożsamość $w$ społeczeństwach zróżnicowanych kulturowo $i$ na pograniczach, Małgorzata Bieńkowska-Ptasznik, Kazimierz Krzysztofek, Adam Sadowski (red.), Wydawnictwo Uniwersytetu w Białymstoku, Białystok.

Peach Ceri, Vertovec Steven, 1997, Islam in Europe - the Politics of Religion and Community, University of Warwick, Basingstoke.

Pędziwiatr Konrad, 2005, Od islamu imigrantów do islamu obywateli. Muzutmanie w krajach Europy Zachodniej, Nomos, Kraków.

PGAP, 2006, Muslim in Europe. Economic - not Religious - Worries Top Their Concerns, Pew Global Attitudes Project (http://pewglobal.org/2006/07/06/muslims-in-europe-economic-worries-top-concerns-about-religious-and-cultural-identity).

PGAP, 2008, Unfavorable Views of Jews and Muslims on the Increase in Europe, Pew Global Attitudes Project (http://pewglobal.org/2008/09/17/unfavorable-views-of-jews-and-muslims-on-the-increase-in-europe).

Pryce-Jones David, 2004, The Islamisation of Europe?, „Commentary”, nr 12.

Rheault Magali, 2007, Majorities Support Women's Rights in North Africa: Most Men Agree with Principles of Gender Equality (http://www.muslimwestfacts.com/mwf/ 29101/Majorities-Support-Womens-Rights-North-Africa-110807.aspx). 
Rheault Magali, Mogahed Dalia, 2008a, Common Ground for Europeans and Muslims Among Them: Similar Views on Honor Killings, Crimes of Passion, the Death Penalty; Gallup Center for Muslim Studies (http://www.gallup.com/poll/107521/common-groundeuropeans-muslims-among-them.aspx).

Rheault Magali, Mogahed Dalia, 2008b, Iranians, Egyptians, Turks: Contrasting Views on Sharia In Egypt, Gallup Center for Muslim Studies (http://www.muslimwestfacts. $\mathrm{com} / \mathrm{mwf} / 108739 /$ Iranians-Egyptians-Turks-Contrasting-Views-Sharia.aspx).

Rheault Magali, Mogahed Dalia, 2008c, Moral Issues Divide Westerners From Muslims in the West: Views Differ Most on Sexual Freedoms, Abortion, Gallup Center for Muslim Studies (http://www.gallup.com/poll/107512/moral-issues-divide-westerners-frommuslims-west.aspx).

Tribalat Michèle, 1995, Faire France. Une grande enquête sur les immigrés et leurs enfants, Broché, Paris.

\section{CULTURE AND ECONOMY IN THE PROCESS OF THE INTEGRATION OF EUROPEAN MUSLIMS}

\section{Sum mary}

The clash between the West and Islam in Western Europe has a double character: religious and sexual. A new World Value Survey shows that we differ extremely in attitudes toward gender equality and sexual liberalization. The sexual clash of civilizations appears not only inside the societies receiving immigrants but also within the immigrant societies and through immigrants' children. The West and Islam are not monolithic opposite sides of conflict - Europeans and Muslims express a wide spectrum of attitudes on moral issues. Europeans and Muslims want democracy, but the Muslims want sharia as a source of legislation too. The clash of cultures in Europe is provoked by economic recession. The clash of values between the second and the third immigrant generations, and between man and woman is especially pronounced in French Muslim suburbs. Unemployed fathers have lost their position to "older brothers", who imposed the specific "macho-culture" oppressive to young women, which are perceived to be too liberal.

\section{Key words/słowa kluczowe}

integration of Muslims / integracja muzułmanów; clash of civilisations / zderzenie cywilizacji; gender equality / równość płci; sexual liberalisation / liberalizacja seksualna; democracy / demokracja; economic exclusion / ekonomiczne wykluczenie 